\title{
Epidemiology of Knee and Hip Arthroplasty: A Systematic Review ${ }^{\S}$
}

\author{
Jasvinder A. Singh ${ }^{*}, 1,2,3,4$ \\ ${ }^{I}$ Medicine Service, Birmingham VA Medical Center and Department of Medicine, University of Alabama, Birmingham, \\ $A L, U S A$ \\ ${ }^{2}$ Center for Surgical Medical acute Care Research and Transitions, Birmingham VA Medical Center, Birmingham, AL, \\ USA \\ ${ }^{3}$ Division of Epidemiology, School of Public Health, University of Alabama, Birmingham, AL, USA \\ ${ }^{4}$ Departments of Health Sciences Research and Orthopedic Surgery, Mayo Clinic School of Medicine, Rochester, MN, USA
}

\begin{abstract}
We present a systematic review of epidemiologic studies of Total Knee Arthroplasty (TKA) and Total Hip Arthroplasty (THA). The studies summarized in this systematic review provide us with estimates of arthroplasty utilization rates, underlying disease frequency and its trends and differences in utilization rates by age, gender and ethnicity among other factors. Among these, many studies are registry-based that assessed utilization rates using data from major orthopedic centers that may provide some understanding of underlying diagnosis and possibly time-trends. Several studies are population-based cross-sectional, which provide estimates of prevalence of TKA and THA. Population-based cohort studies included in this review provide the best estimates of incidence and utilization rates, time-trends and differences in these rates by important patient characteristics (age, gender, ethnicity and others). This article reviews the current published literature in the area and highlights the main findings.
\end{abstract}

Keywords: Total hip arthroplasty, total knee arthroplasty, knee replacement, hip replacement, epidemiology, prevalence, incidence, rate.

\section{INTRODUCTION}

Joint arthroplasty constitutes a major advance in the treatment of chronic refractory joint pain. It is indicated in patients for whom conservative medical therapy has failed. Total Knee and Total Hip Arthroplasty (TKA and THA) are two common surgeries that reduce pain and improve function and quality of life in patients with knee and hip disorders [1-5]. Osteoarthritis is the commonest underlying condition for both TKA and THA. Other conditions leading to TKA and THA include inflammatory arthritis, fracture, dysplasia, malignancy and others. Though there are some differences in outcomes of TKA and THA due to differences in anatomy of the joint and underlying disease conditions [6], most patients achieve significant long-lasting improvement with these procedures.

Due to significant benefits realized with TKA THA, the utilization rates of these procedures have been increasing. In recent years, many studies have examined the incidence and prevalence of knee and hip arthroplasty. The main purpose of this study was to perform a systematic review of studies that examined the prevalence and incidence rates for TKA and THA. Our second aim was to summarize reported differences related to age, gender or race for these procedures.

\footnotetext{
*Address correspondence to this author at the University of Alabama, Faculty Office Tower 805B, $51020^{\text {th }}$ Street S, Birmingham, AL 35294, USA; Tel: 205-934-8158; Fax: 205-966-9685;

E-mail: Jasvinder.md@gmail.com

${ }^{\S}$ The views expressed in this article are those of the authors and do not necessarily reflect the position or policy of the Department of Veterans Affairs or the United States government.
}

\section{METHODS}

Five databases were searched on 09/02/2009 using the key terms "knee/hip arthroplasty", "knee/hip joint replacement" "knee/hip replacement" "total knee/hip arthroplasty" AND "epidemiology" or "prevalence" or "incidence" or "prevalence rate" or "incidence rate". The databases included: [1] The Cochrane Central Register of Controlled Trials (CENTRAL), via The Cochrane Library, Wiley InterScience (www.thecochranelib rary.com), current issue; [2] OVID MEDLINE, 1966-present; [3] CINAHL (via EBSCOHost), 1982-present; [4] OVID SPO RTdiscus, 1949-present ; and [5] Science Citation Index (Web of Science) 1945-present. The list of titles was further narrowed to make it specific to epidemiology of arthroplasty, and not the complications of arthroplasty by expert librarians (LM, JB).

All titles and abstracts were screened by an experienced epidemiologist (J.S.) with expertise in performing systematic reviews. The criteria for including a study were that: (1) it assessed either prevalence or incidence rate; and (2) it was a published article. Studies were excluded if they were abstracts, focused on complications of arthroplasty, or were related to arthroscopy. Studies were grouped into those that examined the rates of knee versus hip and primary versus revision arthroplasty.

Simple estimates such as annual utilization, prevalence and incidence rates are presented. Rates across countries were to be combined to get an overall estimate, if they had been performed during a similar time-period.

\section{RESULTS}

Two expert librarians (L.M., J.B.) performed a focused search of five databases for epidemiology of THA and TKA, 
which identified 106 relevant studies: 34 Medline, 13 CINAHL, 8 Web of science, 4 SportDiscus, 47 CENTRAL. Of these 106 titles and abstracts, four were duplicates and were removed. The PI (J.S.) reviewed titles and abstracts of the remaining 102 studies, of which 27 qualified for the full text review (Fig. 1). Of these, nine studies were excluded: three were reviews or commentaries; one addressed need, but not rates of arthroplasty; one addressed current and future provider-patient ratios; three did not provide prevalence/incidence rates; one addressed appropriateness of THA/TKA. Eighteen studies from the original search met the inclusion and exclusion criteria [7-24]. An additional six studies were identified from the reference lists of included studies [2530]. Thus, 24 studies were included in the systematic review.

\section{Overview of Epidemiology Studies}

Table 1 summarizes the salient features and the man findings of each study included in this review. A few epidemiology studies were performed in population-based samples [7-13, 25-26]. Most other studies of epidemiology of THA and/or TKA were performed in non-population hospital-based cohorts. Age-standardization was performed for most population-based studies, except one [13]. Similarly, most registry-based epidemiology studies were also age-standardized. Most studies were performed in Europe, North America and Australia. Several studies examined time trends in arthroplasty rates over the last few decades, while others examined the arthroplasty utilization rates by age groups, gender and ethnicity. Disparity in utilization rates of THA and TKA by ethnicity, gender, rural/urban residence and region has been described.

\section{Time Trends in Knee Arthroplasty}

The number of hospitalizations for TKA among U.S. Medicare enrollees increased from 145,242 in 2000 to 248,267 in 2006, an increase by 58\% [20]. This translated into an overall TKA incidence rate increase from 5.5 to 8.7 per 1,000 population [20].

In a U.S. study, Kurtz et al. used the National Hospital

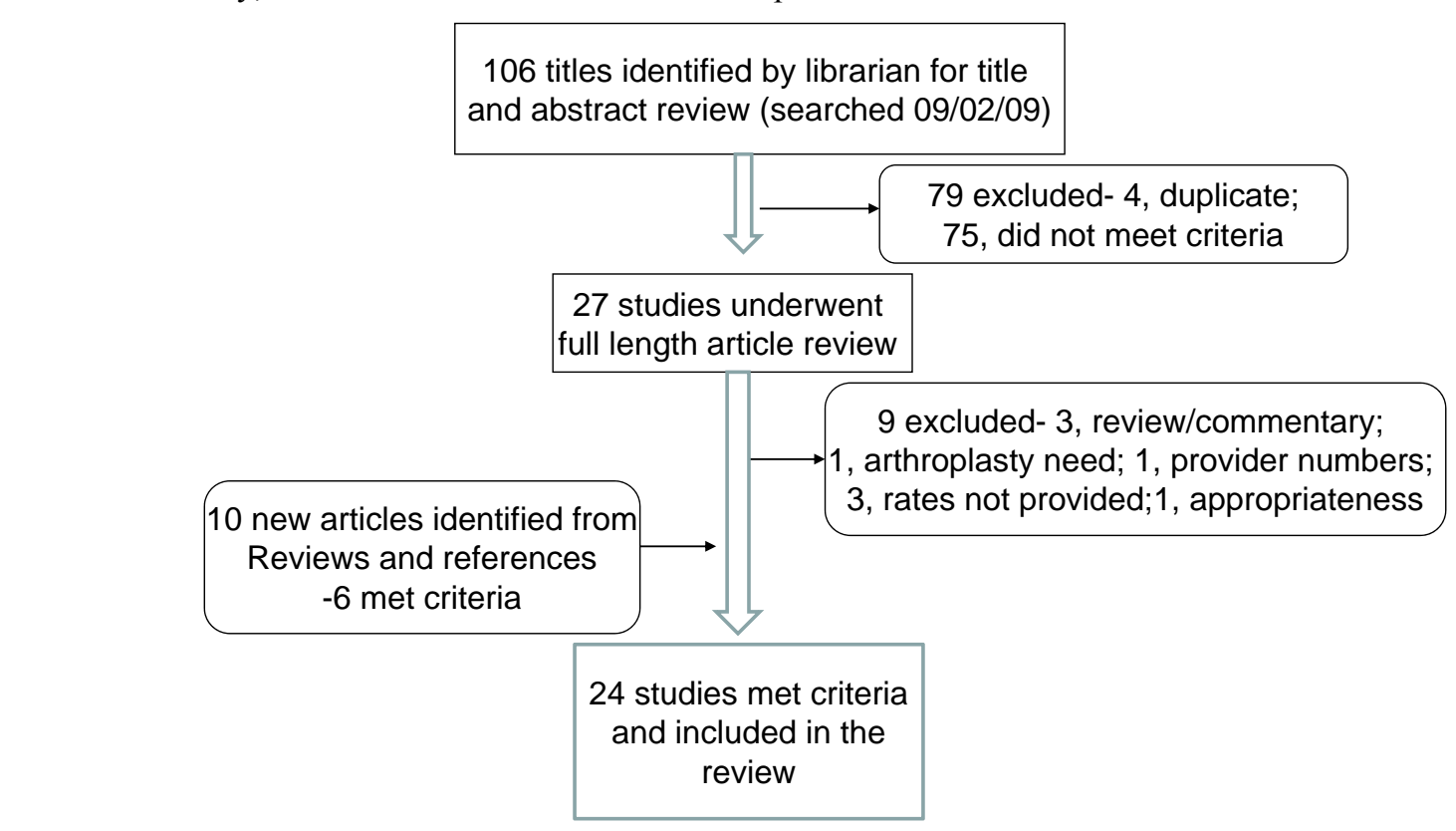

Discharge Survey (NHDS) to study rates of primary and revision THA and TKA [22]. Primary TKA rates increased $170 \%$ from $51 / 100,000$ to $136 / 100,000$ and revision TKA rated increased by $270 \%$ from $4.7 / 100,000$ to $12.5 / 100,000$.

In an analysis of Wisconsin residents 45 years and older from 1990-2000 using the National Inpatient Sample (NIS) dataset, Mehrotra et al. found 1.5 times higher rate for TKA in 2000 [17]. The youngest age group, 45-49 had the largest growth in rate from $9 / 100,000$ to $46 / 100,000$ for men and $17 / 100,000$ to $71 / 100,000$ for women from 1990 to 2000 [17].

In a study of trends from the Swedish Register, the rates of primary TKA increased by 5 -fold in a 20 -year period of observation [11], with similar increases for men and women. While yearly incidence rates for arthroplasties performed for osteoarthritis increased, it remained unchanged for rheumatoid arthritis [11].

\section{Time Trends in Hip Arthroplasty}

Kurtz et al. found a significant increase in annual rates of primary and revision THA from 1990 to 2002 in the U.S. NHDS [22]. There was a $50 \%$ increase in primary THA rate from $47 / 100,000$ to $69 / 100,000$ and a $60 \%$ increase in revision THA rate from $9.5 / 100,000$ to $15.2 / 100,000$.

In a study of time-trends in THA in Iceland, the total number of THAs increased from 94 THAs in 1982 to 323 THAs in 1996 [7]. The annual incidence increased from 43 to 133 per 100,000 people, an increase by 3 -fold. The annual incidence of THA for primary osteoarthritis per 100,000 increased 68 in 1982-86 to 114 in 1992-1996. Annual incidence of revision THA increased from 2.5 per 100,000 in 1982 to 25 per 100,000 in 1996 [7].

In a population-based study in Denmark, the incidence rates of primary and revision THA increased by 30\% (101 to 131 per 100,000$)$ by $10 \%$ (19.2 to 20.7 per 100,000$)$ from 1996 to 2002 [9]. The increase in primary THAs was noted

Fig. (1). Flow chart of included studies. 
Table 1. Summary of Findings from Included Studies

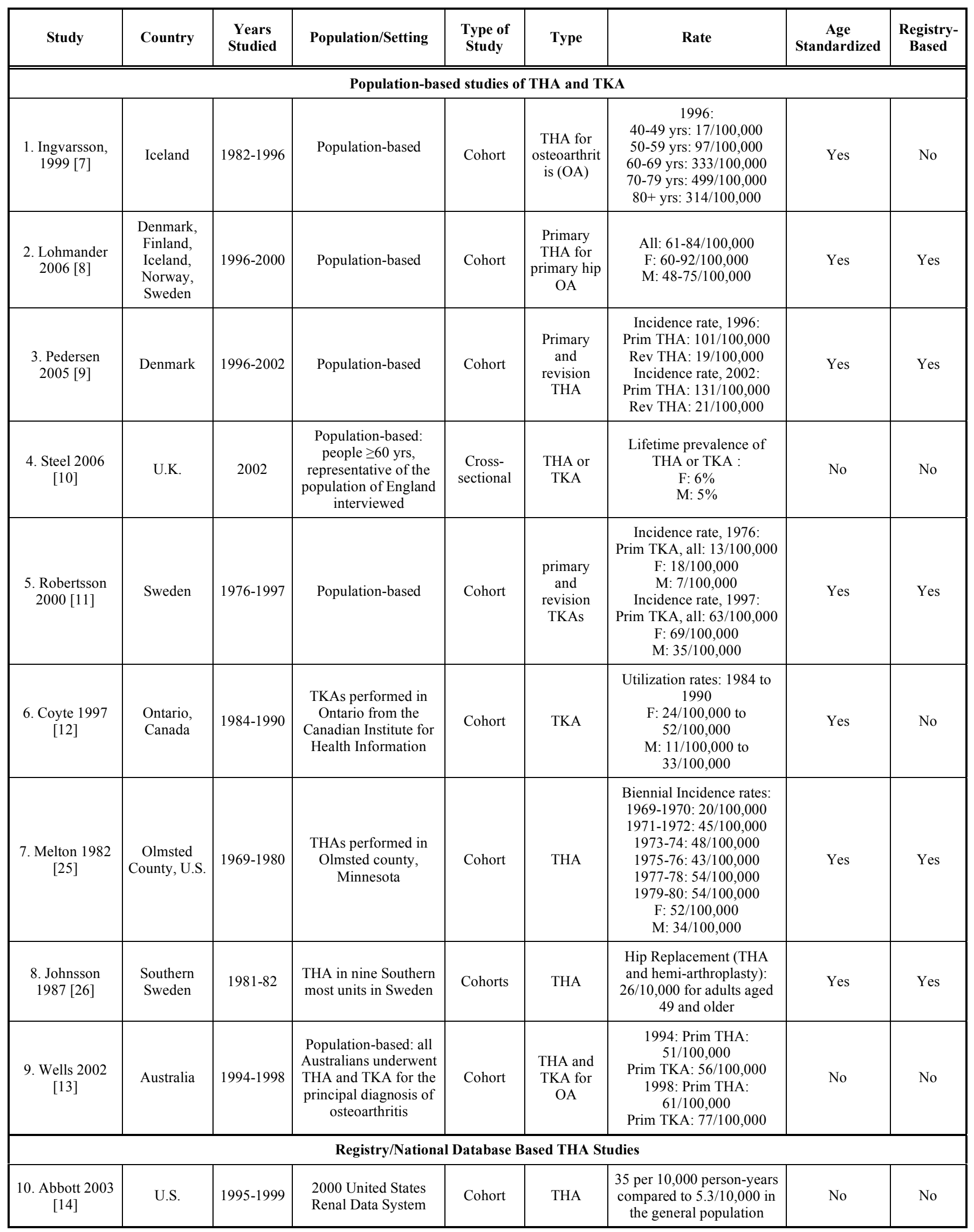




\begin{tabular}{|c|c|c|c|c|c|c|c|c|}
\hline Study & Country & $\begin{array}{l}\text { Years } \\
\text { Studied }\end{array}$ & Population/Setting & $\begin{array}{l}\text { Type of } \\
\text { Study }\end{array}$ & Type & Rate & $\begin{array}{c}\text { Age } \\
\text { Standardized }\end{array}$ & $\begin{array}{l}\text { Registry- } \\
\text { Based }\end{array}$ \\
\hline $\begin{array}{l}\text { 112. } \operatorname{Kim}_{[16]} 2008 \\
\end{array}$ & South Korea & $2002-2006$ & $\begin{array}{l}\text { National Database with } \\
\text { reimbursement records } \\
\text { from all South Korean } \\
\text { medical facilities }\end{array}$ & $\begin{array}{l}\text { Cross- } \\
\text { sectional }\end{array}$ & THA & $\begin{array}{c}\text { 2002: F: } 1.7 / 100,000 \\
\text { M: } 1.4 / 100,000 \\
\text { 2005: F: } 3.1 / 100,000 \\
\text { M: } 2 / 100,000\end{array}$ & Yes & Yes \\
\hline $\begin{array}{c}\text { 13. Birrell } 1999 \\
\text { [27] }\end{array}$ & England & 1996 & $\begin{array}{c}\text { Hospital Episode } \\
\text { System (HES) for } \\
\text { identification of all } \\
\text { THAs }\end{array}$ & $\begin{array}{l}\text { Cross- } \\
\text { sectional }\end{array}$ & THA & $\begin{array}{l}\text { 1996: All: } 87 / 100,000 \\
\text { F: } 109 / 100,000 \\
\text { M: } 65 / 100,000\end{array}$ & No & No \\
\hline $\begin{array}{l}\text { 14. Hoaglund } \\
1995 \text { [28] }\end{array}$ & $\begin{array}{l}\text { San } \\
\text { Francisco, } \\
\text { U.S. }\end{array}$ & 1984-1988 & $\begin{array}{l}\text { Hospital records from } \\
17 \text { hospitals in "San } \\
\text { Francisco country" }\end{array}$ & $\begin{array}{l}\text { Cross- } \\
\text { sectional }\end{array}$ & $\begin{array}{c}\text { THA for } \\
\text { primary hip } \\
\text { OA }\end{array}$ & $\begin{array}{c}\text { White: } 76 / 100,000 \\
\text { Black: } 35 / 100,000 \\
\text { Hispanic: } 13 / 100,000 \\
\text { Filipino: } 7 / 100,000 \\
\text { Japanese: } 17 / 100,000 \\
\text { Chinese: } 8 / 100,000\end{array}$ & Yes & No \\
\hline $\begin{array}{l}\text { 15. Puolakka } \\
2001 \text { [29] }\end{array}$ & Finland & 1999 & & Cohort & THA & $\begin{array}{c}\text { 1999: Prim THA: } \\
\text { 93/100,000 } \\
\text { Rev THA: } 23 / 100,000\end{array}$ & No & Yes \\
\hline \multicolumn{9}{|c|}{ Registry/National Database Based TKA Studies } \\
\hline $\begin{array}{l}\text { 16. Mehrotra } \\
2005 \text { [17] }\end{array}$ & U.S. & $1990-2000$ & $\begin{array}{c}\text { Wisconsin Inpatient } \\
\text { Hospital Database for } \\
\text { Wisconsin residents } \\
\geq 45 \text { years }\end{array}$ & $\begin{array}{l}\text { Cross- } \\
\text { sectional }\end{array}$ & $\begin{array}{l}\text { Primary } \\
\text { TKA }\end{array}$ & $\begin{array}{l}\text { 1990: All (age- } \\
\text { standardized): } 162 / 100,00 \\
\text { F: } 30 / 100,000 \\
\text { M: } 23 / 100,000 \\
\text { 2000: All (age- } \\
\text { standardized): : } \\
\text { 294/100,000 } \\
\text { F: } 46 / 100,000 \\
\text { M: } 35 / 1000,000\end{array}$ & Yes & No \\
\hline $\begin{array}{l}\text { 19.Centers for } \\
\text { Disease Control } \\
\text { and Prevention } \\
2009[20]\end{array}$ & U.S. & $\begin{array}{c}2000 \& \\
2006\end{array}$ & $\begin{array}{c}\text { Medicare enrollees } \\
\text { aged } \geq 65 \text { years, not } \\
\text { members of Health } \\
\text { Maintenance } \\
\text { organizations and } \\
\text { entitled to Medicare } \\
\text { part A } \\
\text { 2000: } 26,585,955 \\
\text { 2006: } 28,382,683\end{array}$ & $\begin{array}{l}\text { Cross- } \\
\text { sectional }\end{array}$ & TKA & $\begin{array}{c}\text { 2000: } 5.5 / 1,000 \\
\text { 2006: } 8.7 / 1,000 \\
\text { Racial Disparity: } \\
\text { Whites: } 5.7 / 1,000 \text { in } 2000 \\
\text { and } 9.2 / 1,000 \text { in } 2006 \\
\text { Blacks: } 3.6 / 1,000 \text { in } 2000 \\
\text { and } 5.6 / 1,000 \text { in } 2006 \\
\text { Male: } 4.6 \text { in } 2000,7.3 \text { in } \\
2006 \\
\text { Female: } 6.1 \text { in } 2000,9.8 \text { in } \\
2006\end{array}$ & Yes & No \\
\hline \multicolumn{9}{|c|}{ Registry/National Database Based THA and TKA Studies } \\
\hline $\begin{array}{l}\text { 20. Jarvholm } \\
2007 \text { [21] }\end{array}$ & Sweden & $1960-1992$ & $\begin{array}{c}\text { Construction worker } \\
\text { cohort participating in } \\
\text { national health control } \\
\text { program from }\end{array}$ & Cohort & $\begin{array}{l}\text { THA \& } \\
\text { TKA }\end{array}$ & $\begin{array}{c}\text { Ranged between } \\
\text { professions from } 447- \\
857 / \text { million person-years } \\
\text { for THA; } 123-407 / \text { million } \\
\text { person-years for TKA }\end{array}$ & Yes & Yes \\
\hline $\begin{array}{l}\text { 21. Kurtz } 2007 \\
{[22]}\end{array}$ & U.S. & $1990-2002$ & $\begin{array}{l}\text { National Hospital } \\
\text { Discharge Survey } \\
\text { (NHDS), a } \\
\text { representative sample } \\
\text { of all non-federal non- } \\
\text { military in-patient } \\
\text { facilities }\end{array}$ & $\begin{array}{l}\text { Cross- } \\
\text { sectional }\end{array}$ & $\begin{array}{l}\text { THA and } \\
\text { TKA }\end{array}$ & $\begin{array}{c}\text { 1990: Prim THA: } \\
\text { 47/100,000 } \\
\text { Rev THA: } 9.5 / 100,000 \\
\text { Prim TKA: } 51 / 100,000 \\
\text { Rev TKA: } 4.7 / 100,000 \\
\text { 2002: Prim THA: } \\
\text { 69/100,000 } \\
\text { Rev THA: } 15.2 / 100,000 \\
\text { Prim TKA: } 136 / 100,000 \\
\text { Rev TKA: } 12.5 / 100,000\end{array}$ & Yes & No \\
\hline
\end{tabular}




\begin{tabular}{|c|c|c|c|c|c|c|c|c|}
\hline Study & Country & $\begin{array}{l}\text { Years } \\
\text { Studied }\end{array}$ & Population/Setting & $\begin{array}{l}\text { Type of } \\
\text { Study }\end{array}$ & Type & Rate & $\begin{array}{c}\text { Age } \\
\text { Standardized }\end{array}$ & $\begin{array}{l}\text { Registry- } \\
\text { Based }\end{array}$ \\
\hline $\begin{array}{l}\text { 22. Melzer } 2003 \\
{[23]}\end{array}$ & U.S. & 1993 & $\begin{array}{l}1993 \text { National Mortality } \\
\text { Follow back Survey in } \\
\text { people } \geq 65 \text { years, who } \\
\text { had THA or TKA }<1 \\
\text { year from their death }\end{array}$ & $\begin{array}{l}\text { Cross- } \\
\text { sectional }\end{array}$ & $\begin{array}{l}\text { TKA and } \\
\text { THA }\end{array}$ & $\begin{array}{c}\text { Prevalence: THA: } 15.5 \% \\
\text { TKA: } 6 \%\end{array}$ & No & No \\
\hline $\begin{array}{l}\text { 23. Wells } 2004 \\
{[24]}\end{array}$ & Australia & 1994-2002 & $\begin{array}{l}\text { Male Veterans } \\
\text { compared with male } \\
\text { civilians for THA and } \\
\text { TKA for OA in } \\
\text { Southern Australia }\end{array}$ & Cohort & $\begin{array}{l}\text { THA and } \\
\text { TKA for } \\
\text { OA }\end{array}$ & $\begin{array}{c}\text { THA: Standardized } \\
\text { morbidity ratio (SMR)- } 0.715 \\
\text { TKA: SMR-0.987 }\end{array}$ & Yes & Yes \\
\hline $\begin{array}{l}\text { 24. Havelin } 2000 \\
{[30]}\end{array}$ & Norway & 1997 & $\begin{array}{l}\text { Norwegian register } \\
\text { established } 1988\end{array}$ & Cohort & THA & $\begin{array}{c}\text { 1997: prim THA: } \\
\text { 120/100,000 } \\
\text { Rev THA: } 24 / 100,000 \\
\text { Prim TKA: } 34 / 100,000\end{array}$ & & \\
\hline
\end{tabular}

THA, Total Hip Arthroplasty; TKA, Total Knee Arthroplasty; OA, osteoarthritis, F, female; M, male; Prim, primary; Rev, revision.

in all age groups, but was highest for patients aged 50-59 and lowest for those aged 10-49 [9]. An increase in incidence rates from 1996 to 2002 was noted for all diagnoses including osteoarthritis, except rheumatoid arthritis, for which the incidence rate decreased [9].

In a study using the Hospital Episode System in England, rate of THA was estimated at $87 / 100,000$ in 1996 , slightly higher in women $(109 / 100,000)$ than men $(64 / 100,000)$ [27]. Projection of time-trend revealed that a $40 \%$ increase in THA rates would be noted by year 2030, with higher increase in men (51\%) than women (33\%) [27].

\section{Age Differences in Arthroplasty Rates}

In a U.S. study of Medicare recipients comparing the rates of TKA between 2000 and 2006, rates in patients aged 65-74, $75-84$ and $\geq 85$ years (all rates per 1,000 population) were 5.4 , 6.6 and 2.6 in 2000; and 9.1, 10.2 and 4.0 in 2006, respectively [20].

\section{Disparity in Arthroplasty Utilization}

A variety of factors have been associated with disparity in the rates of knee and hip arthroplasty. Following is a summary of current evidence supporting the existence of disparity in utilization of arthroplasty.

Race/Ethnicity: In a U.S., study, Caucasians had TKA rates of 5.7 and 9.2 per 1,000 and African-Americans had rates of 3.6 and 5.6 per 1,000 , respectively [20]. The TKA rates were $37 \%$ lower among blacks than whites in 2000 and $39 \%$ lower in 2006. In both years, the ethnic/racial disparity was lower among women (23\% and $28 \%$ ) than among men (63\% and 60\%) [20].

Caucasians had the highest annual age-standardized rates of THA in San Francisco residents in a study from 1984-88 [28]. Blacks, Japanese, Hispanics, Chinese and Filipino had lower rates in decreasing order compared to Caucasians.

Gender: Three studies reported similar increase in utilization rates between men and women undergoing arthroplasty. In a U.S. study using the NIS, the increase was noted both for women and men at a similar rate [17]. In a Danish study, the increase in THA incidence rates from 1996 to 2002 were similar in men and women [9]. In a study of nationally representative sample of 7,100 people aged $\geq 60$ years from England, similar rates of existing knee or hip joint replacement were reported for women (6\%) and men (5\%) [10]. In a U.S. Medicare study, women had TKA utilization rates of 6.1 and 9.9 in 2000 and 2006; respective rates in men were 4.6 and 7.3, respectively [20]. In a national study from South Korea, women had more severe knee disease, higher BMI and were 7-8 times more likely to undergo TKA than men [18].

Region: A study from England found lower prevalence of existing knee or hip joint replacement for Northern compared to Southern region, although the need was significantly greater in North compared to South [10]. In the same study, the need was greater in women and increased from wealthiest to poorest quintile, but receipt did not differ by sex or socio-economic group. Melton et al. examined THA utilization rates in Olmsted County, Minnesota, USA from 1969 to 1980 [25]. Adjusted THA rates were lower in rural than urban residents of Olmsted County, 29/100,000 versus 49/100,000, respectively. Similarly, a study in Ontario, Canada found differences in TKA rates between different parts of Ontario [12] with Southern Ontario regions having significantly higher provincial population than the provincial population.

Veteran Status: One Study compared rates of TKA and THA between Veterans and civilians in Southern Australia between 1994 and 2002 [24]. The overall rates were similar for TKA, but significantly lower in veterans for THA versus civilians. Veterans in age group 65-74 were less likely, and those in age groups $75-84$ and $\geq 85$ years more likely than civilians to have THA [24].

Rates of utilization could not be pooled across countries due to a wide variation in rates, time-periods and presentation of data for different groups.

\section{CONCLUSION}

In this systematic review of the literature, we found that the utilization rates for THA and TKA have increased over the last 2-3 decades. With aging of the population and increased longevity, the TKA and THA utilization rates are projected to increase even further. The rates vary by country of study, which may be due to differences in socioeconomic status, health care delivery systems, patient preferences and/or prevalence of osteoarthritis, the most common underlying cause for THA/TKA. A few studies have been performed on a 
population-level, providing information on prevalence and incidence, but more work is needed in this area. Disparities have been noted based on ethnicity, gender and region. While important advances have been made in arthroplasty outcomes, equity remains a challenge. Future studies should examine the causes of these disparities and test interventions that can reduce the disparities in use of THA and TKA.

\section{ACKNOWLEDGEMENTS}

I thank Lisa McGuire and Jim Beattie from the Medical library at the University of Minnesota for performing the searches.

Grant Support: NIH CTSA Award 1 KL2 RR024151-01 (Mayo Clinic Center for Clinical and Translational Research) and the Department of Orthopedic Surgery, Mayo Clinic School of Medicine, Rochester, MN.

Financial Conflict: There are no financial conflicts related to this work. J.A.S. has received speaker honoraria from Abbott; research and travel grants from Allergan, Takeda, Savient, Wyeth and Amgen; and consultant fees from Savient and URL pharmaceuticals.

\section{REFERENCES}

[1] Rissanen P, Aro S, Slatis P, Sintonen H, Paavolainen P. Health and quality of life before and after hip or knee arthroplasty. J Arthroplasty 1995; 10(2): 169-75.

[2] March LM, Cross MJ, Lapsley H, et al. Outcomes after hip or knee replacement surgery for osteoarthritis. A prospective cohort study comparing patients' quality of life before and after surgery with agerelated population norms. Med J Aust 1999; 171(5): 235-8.

[3] Jones CA, Voaklander DC, Johnston DW, Suarez-Almazor ME. Health related quality of life outcomes after total hip and knee arthroplasties in a community based population. J Rheumatol 2000; 27(7): 1745-52.

[4] Ethgen O, Bruyere O, Richy F, Dardennes C, Reginster JY. Healthrelated quality of life in total hip and total knee arthroplasty. A qualitative and systematic review of the literature. J Bone Joint Surg Am 2004; 86-A(5): 963-74.

[5] Jones CA, Voaklander DC, Suarez-Alma ME. Determinants of function after total knee arthroplasty. Phys Ther 2003; 83(8): 696-706.

[6] Rand JA, Trousdale RT, Ilstrup DM, Harmsen WS. Factors affecting the durability of primary total knee prostheses. J Bone Joint Surg Am 2003; 85-A(2): 259-65.

[7] Ingvarsson T, Hagglund G, Jonsson H, Jr., Lohmander LS. Incidence of total hip replacement for primary osteoarthrosis in Iceland 1982-1996. Acta Orthop Scand [Comparative Study Research Support, Non-U.S. Gov't] 1999; 70(3): 229-33.

[8] Lohmander LS, Engesaeter LB, Herberts P, Ingvarsson T, Lucht U, Puolakka TJS. Standardized incidence rates of total hip replacement for primary hip osteoarthritis in the 5 Nordic countries: similarities and differences. Acta Orthop [Comparative Study Research Support, NonU.S. Gov't] 2006; 77(5): 733-40.

[9] Pedersen AB, Johnsen SP, Overgaard S, Soballe K, Sorensen HT, Lucht U. Total hip arthroplasty in Denmark - Incidence of primary operations and revisions during 1996-2002 and estimated future demands. Acta Orthop 2005; 76(2): 182-9.

[10] Steel N, Melzer D, Gardener E, McWilliams B. Need for and receipt of hip and knee replacement--a national population survey. Rheumatology (Oxford) [Research Support, Non-U.S. Gov't] 2006; 45(11): 1437-41.

[11] Robertsson O, Dunbar MJ, Knutson K, Lidgren L. Past incidence and future demand for knee arthroplasty in Sweden: a report from the Swedish Knee Arthroplasty Register regarding the effect of past and future population changes on the number of arthroplasties performed. Acta Orthop Scand [Research Support, Non-U.S. Gov't] 2000; 71(4): 376-80.

[12] Coyte P, Wang PP, Hawker G, Wright JG. The relationship between variations in knee replacement utilization rates and the reported prevalence of arthritis in Ontario, Canada. J Rheumatol [Research Support, Non-U.S. Gov't Research Support, U.S. Gov't, P.H.S.] 1997; 24(12): 2403-12.

[13] Wells VM, Hearn TC, McCaul KA, Anderton SM, Wigg AER, Graves SE. Changing incidence of primary total hip arthroplasty and total knee arthroplasty for primary osteoarthritis. J Arthroplasty 2002; 17(3): 26773.

[14] Abbott KC, Bucci JR, Agodoa LY. Total hip arthroplasty in chronic dialysis patients in the United States. Jpn J 2003; 16(1): 34-9.

[15] Clark DA, Mason KT, Belmont P. Incidence and outcomes of total hip arthroplasty among US Army aviators. Military Medicine 2001; 166(2): $132-4$.

[16] Kim HA, Koh SH, Lee B, et al. Low rate of total hip replacement as reflected by a low prevalence of hip osteoarthritis in South Korea. Osteoarthritis Cartilage [Research Support, Non-U.S. Gov't] 2008; 16(12): 1572-5.

[17] Mehrotra C, Remington PL, Naimi TS, Washington W, Miller R. Trends in total knee replacement surgeries and implications for public health, 1990-2000. Public Health Rep 2005; 120(3): 278-82.

[18] Kim HA, Kim S, Seo YI, et al. The epidemiology of total knee replacement in South Korea: national registry data. Rheumatology (Oxford) [Research Support, Non-U.S. Gov't] 2008; 47(1): 88-91.

[19] Juni P, Dieppe P, Donovan J, Peters T, et al. Population requirement for primary knee replacement surgery: a cross-sectional study. [comment]. Rheumatology (Oxford) [Comment Research Support, Non-U.S. Gov't] 2003; 42(4): 516-21.

[20] Centers for Disease Control and Prevention. Racial disparities in total knee replacement among Medicare enrollees--United States, 20002006. MMWR Morb Mortal Wkly Rep 2009; 58(6): 133-8.

[21] Jarvholm B, From C, Lewold S, Malchau H, Vingard E. Incidence of surgically treated osteoarthritis in the hip and knee in male construction workers. Occup Environ Med [Multicenter Study Research Support, Non-U.S. Gov't] 2008; 65(4): 275-8.

[22] Kurtz S, Mowat F, Ong K, Chan N, Lau E, Halpern M. Prevalence of primary and revision total hip and knee arthroplasty in the United States from 1990 through 2002. J Bone Joint Surg Am 2005; 87(7): 1487-97.

[23] Melzer D, Guralnik JM, Brock D. Prevalence and distribution of hip and knee joint replacements and hip implants in older Americans by the end of life. Aging Clin Exp Res [Research Support, Non-U.S. Gov't] 2003; 15(1): 60-6.

[24] Wells V, Hearn T, Heard A, Lange K, Rankin W, Graves S. Incidence and outcomes of knee and hip joint replacement in veterans and civilians. [see comment]. ANZ J Surg [Comparative Study Research Support, Non-U.S. Gov't] 2006; 76(5): 295-9.

[25] Melton LJ, 3rd, Stauffer RN, Chao EY, Ilstrup DM. Rates of total hip arthroplasty; a population-based study. N Engl J Med 1982; 307(20): $1242-5$.

[26] Johnsson R, Lidgren L. Incidence of hip replacement in southern Sweden. Acta Orthop Scand 1987; 58(3): 226-30.

[27] Birrell F, Johnell O, Silman A. Projecting the need for hip replacement over the next three decades: influence of changing demography and threshold for surgery. Ann Rheum Dis 1999; 58(9): 569-72.

[28] Hoaglund FT, Oishi CS, Gialamas GG. Extreme variations in racial rates of total hip arthroplasty for primary coxarthrosis: a populationbased study in San Francisco. Ann Rheum Dis 1995; 54(2): 107-10.

[29] Puolakka TJ, Pajamaki KJ, Halonen PJ, Pulkkinen PO, Paavolainen P, Nevalainen JK. The Finnish Arthroplasty Register: report of the hip register. Acta Orthop Scand.2001; 72(5): 433-41.

[30] Havelin LI, Engesaeter LB, Espehaug B, Furnes O, Lie SA, Vollset SE. The Norwegian Arthroplasty Register: 11 years and 73,000 arthroplasties. Acta Orthop Scand 2000; 71(4): 337-53. 